на нумізматичне видання на тему:

\title{
«Фальшивомонетничество в Центральной и Восточной Европе в эпоху Средневековья и раннего Нового времени» ${ }^{1 .}$
}

Рецензент: Олексій Бакалеиь - кандидат історичних наук, доцент кафедри історії, правознавства та методики навчання Глухівського національного педагогічного університету імені Олександра Довженка, здобувач Інституту історії НАН України, член НСКУ.

У другій половині 2017 р. вийшла у світ монографія провідного наукового співробітника сектору нумізматики, фалеристики, медальєрики і сфрагістики Національного музею історії України, кандидата історичних наук Бойка-Гагаріна А.С. «Фальшивомонетництво у Центральній та Східній Свропі в добу Середньовіччя та раннього Нового часу».

Рецензована книга - перша у вітчизняній історіографії фундаментальна праця знаного фахівця в галузі європейської та української нумізматики з проблем фальшування монет. Вихід монографії А. Бойка-Гагаріна став справжньою науковою подією - наразі це єдина в незалежній Україні нумізматична праця з таким великим обсягом залучених писемних та монетних джерел, присвяченим приватним підробкам монет країн Центральної та Східної Свропи в добу середньовіччя та раннього нового часу.

Робота розкриває історію фальшивомонетної справи від початків карбування монет в Європі до початку XVIII ст., вона є своєрідним каталогом і методичним посібником водночас для визначення реальних і фальшивих монет. У праці А.С. Бойка-Гагаріна узагальнено його власні результати багаторічних нумізматичних досліджень з проблем фальшування різних монетних номіналів, серед яких 4 опубліковані у закордонних та 39 - у вітчизняних виданнях (з яких 4 у співавторстві). Наукове дослідження виконане автором у навчально-науковому Центрі дослідження проблем нумізматики та історії грошового обігу при ДВНЗ «ПереяславХмельницький державний педагогічний університет ім. Григорія Сковороди» (науковий редактор - доктор історичних наук, професор Центральноукраїнського НТУ В.М. Орлик).

За своєю структурою монографія не викликає зауважень. Вона складається зі списку скорочень, вступу, 23 глав, результатів досліджень (українською та англійською мовами), опису до ілюстрацій (668 позицій), переліку джерел (17 позицій), списку використаної літератури (393 позицій), що представлена українською, польською, російською, німецькою, англійською, турецькою, угорською, датською, чеською, словацькою, сербською, молдавською, нідерландською, литовською, іспанською та білоруською мовами, електронних ресурсів (8 позицій). Суттєве значення мають два функціональних додатки у вигляді таблиць (1 таблиця «Склад сплаву поверхні фальшивих монет за даними РФА»; 2 таблиця «Топографія знахідок фальшивих монет»).

У рецензованій праці (глави 2-19) автор дослідив основні типи фальшивих монет часів Київської і Галицької Русі, Великого князівства Литовського, Польського королівства, Речі Посполитої, Чехії, Угорщини, Прибалтійських володінь Швеції, Молдавії, Трансільванії, Голландської республіки, Московського царства, Золотої Орди, Кримського ханства, Османської імперії, Тевтонського ордену у Пруссії та Лівонії, Шотландії, Венеціанської республіки, Іспанії та інших країн Європи, монети яких перебували у грошовому обігу Європи та України зокрема. Глави 1, 20-23 присвячені характеристиці технологій виробництва фальшивих і підробних монет на різних етапах розвитку монетної справи, - від Високого середньовіччя до ранньої Нової доби, співвідношенню фальшивомонетництва і закону.

Фальшивомонетництво у Центральній та Східній Свропі в добу Середньовіччя та раннього Нового часу. - Авт. 
У главі 22 «Топографія знахідок фальшивих монет» автор монографії на основі зібраних даних відзначив райони найбільшої концентрації знахідок фальшивих монет, визначив специфіку типів тих монет, які зустрічаються в різних регіонах України (668 позицій), наголосив на домінуванні фальшаків серед випадкових знахідок, а не у складі монетних скарбів. БойкоГагарін робить важливий висновок про те, що найбільшу кількість фальшивих монет зафіксовано у Володимир-Волинському та Луцькому районах, через які у різний час проходили найважливіші торгові шляхи із Волині на Поділля, Галичину, Наддніпрянщину, Молдавію, Польщу, Литву, Московію, в Золоту Орду.

На різноманітних фактах дослідник доводить думку про те, що виробництво фальшивих монет в усі часи було надзвичайно прибутковою, хоча й небезпечною, справою. Автори підробок були переважно анонімними, а їх соціальне походження найрізноманітнішим. Окрім традиційних для нумізматики термінів: «фальшива монета», «фальшак», «фальсифікат», «монетна підробка» А. Бойко-Гагарін пропонує власні терміни: «фальсифікат минулого», «підробка минулої епохи», «Нумізматика - (від латинської «nomisma» - монета) наука, яка вивчає монети, скарби, колекції, товарно-грошові відносини і техніку виготовлення монет, а також кустарні підробки монет того часу».

Провівши аналіз різних поглядів зарубіжних та вітчизняних учених-нумізматів (М. Котляра, О. Огуя, Р. Шуста та інших) стосовно питання класифікації фальшивих монет, А. Бойко-Гагарін сміливо пропонує нову, більш повну, на нашу думку, класифікацію фальшивих монет минулого: монети приватних емітентів, які мали право монетної регалії (імітації); підробки, таємно виготовлені на монетному дворі чи за допомогою вкрадених з монетного двору інструментів; приватні «кустарні» підробки; нанесення фальшивих надкарбувань; нанесення оригінальних надкарбувань на фальшиві монети; фальшиві перекарбування.

Автор, що цілком логічно, при написанні тексту монографії ставить перед собою ряд завдань, передусім, з’ясувати питання ступеня розробки теми дослідження. Результати, отримані автором, відкривають нові, раніше не досить системно досліджені, сторінки історії грошового обігу українських регіонів, участі у ньому фальшивих монет, а також деякі спірні актуальні питання європейської та вітчизняної нумізматики доби середньовіччя та ранньої нової доби.

До позитивних рис рецензованого видання належить розлога джерельна база, високий ступінь аналітичності та глибина узагальнень, використання сучасних технічних і методичних підходів для ідентифікації об єктів та методичного інструментарію дослідження.

До недоліків видання А. Бойка-Гагаріна слід віднести відсутність у додатках словника нумізматичних термінів, насамперед монетних номіналів, які найчастіше у досліджуваний період піддавалися фальшуванню.

Попри незначні недоліки хочемо відзначити високий науковий рівень викладу матеріалу, якісну поліграфію, ілюстративний матеріал праці. Монографія А. Бойка-Гагаріна добре прислужиться історикам, економістам, музеєзнавцям, нумізматам, колекціонерам, усім, хто цікавиться зарубіжною та вітчизняною історією і культурою.

Олексій Бакалець
30. 03. $2018 \mathrm{p}$. 


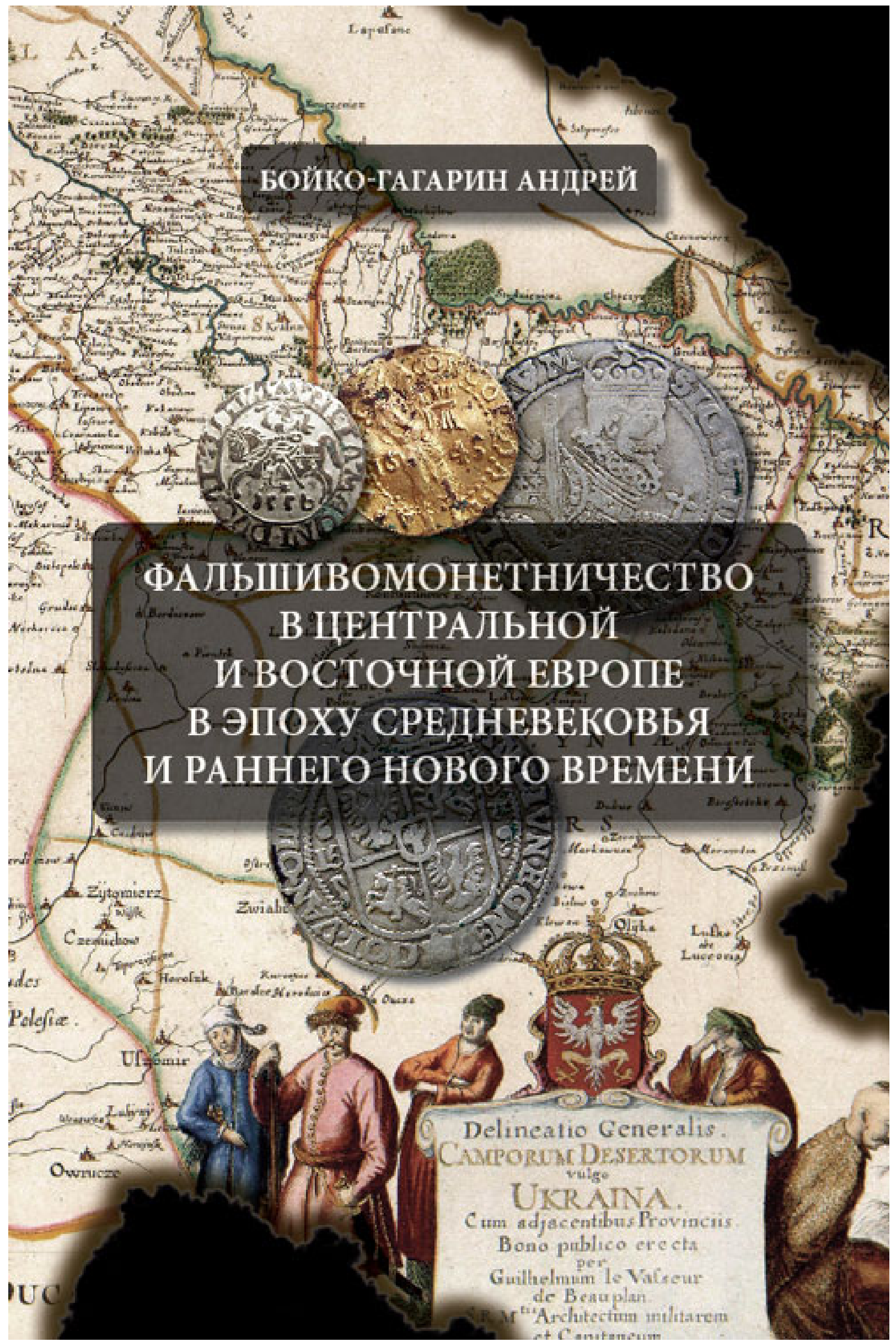

Рис. 1. Лицьова сторінка монографії Андрія Бойка-Гагаріна 